\title{
Development of a Crop Cultivation and Water Reuse System
}

\author{
Sayan Das ${ }^{1, *}$ and Mrinmoy Majumder ${ }^{2}$ \\ ${ }^{1}$ Faculty of Electrical Engineering Dept., Aliah University, Kolkata, India \\ ${ }^{2}$ Assistant Prof. HIE Dept., National Institute of Technology Agartala, Tripura, \\ India \\ 'dassayan90@gmail.com, ${ }^{2}$ mmajumder15@gmail.com
}

\begin{abstract}
Water, food and light are the basic need of the living things. Without these three things it becomes impossible for the society to complete their daily lifecycle. Among these food is the valuable thing based on which people can sustain their life. But now a day's food demand increases but production of food is not available in that much amount to maintain the demand supply ratio. So for solving this problem the only solution is to increase the production. Many researchers try several processes to increase the supply of food. But all the solution has own disadvantages. Based on this research work we try to rectify the disadvantages and find a new way to solve the food scarcity problem in our research work. This paper contains the overall research overview.
\end{abstract}

Keywords: Food Scarcity, Vertical Irrigation System, Water reuse policy, scenario analysis

\section{Introduction}

Food is the most essential resource required for the sustenance of human population[7]. But in most countries in our world due to the lack of supply \& monitoring the basic resources are mis-utilized. This resulted in scarcity for the food. Along with growing population density one of the major reason for the uncertainty can be attributed to nonoptimal utilization of the resources. The next section tries to highlight this point with latest literatures and also discusses about the possible situations available in this regard.

\subsection{Food Security}

The assessment of risk due to water scarcity is not limited to the "demand and supply" problem of fresh and drinking water. Limited amount of freshwater will also hamper the agricultural sector [8]. The Literature review says that there is a dramatic increase in the demand for food because of global population density will increases by 2.25 billion people from today's level and will reach 9.15 billion by 2050[1]. For a low- and middleincome countries agricultural output annually increased to $60 \%$ to $70 \%$. But the quality of land has remained unchanged. In fact according to the report of Food and agriculture organization the arable land per human being may reduce by 0.20 hectare in 2020, compared to 0.45 hectare in 1965 [9]. Also the land erosion problem is a big issue [10]. To satisfying the food demand of the world the vertical irrigation system is introduced [11].

\section{Vertical Irrigation system}

To overcome this challenge scientist Despommier approaches a vertical farming technique which solves the food problem of $21^{\text {st }}$ century. He invents the original High rise farm. This multi storey farming system could also solve the energy and transportation cost. It reduces the greenhouses gas emissions too. Another advantage is that land which 
is used for agriculture could be returned to nature-vital ecosystems such as forests, which stored $\mathrm{CO}_{2}$, thereby removing it from the atmosphere in that way.

According to the Professor Despommier, this vertical irrigation system which will be farm in a 30-stored building might able to supply 50,000 people food in future.

The limitation of the available solution discussed in the next section.

\section{A. Limitations of the Above System}

There are many rain water harvesting, water reuse and vertical irrigation schemes installed all over the world. But each of them is used separately. None of them are ever used in a combined way. The benefits of combined over separate systems are explained in Table 1.

\subsection{Drawbacks of the Above Solution}

Table 1. Sharing the Production of Energy, Food and Water Separately and Combined Manner

\begin{tabular}{|c|c|c|c|}
\hline \multirow[t]{2}{*}{ Parameter } & \multicolumn{2}{|r|}{ Food Production } & $\begin{array}{l}\text { Food production using } \\
\text { recycled water }\end{array}$ \\
\hline & [12] & {$[13]$} & \\
\hline Cost & $\begin{array}{c}\text { Per acre } \\
\text { costing } 5395\end{array}$ & $\begin{array}{c}\text { Variable cost - \$68.56(for dry land) and } \\
\$ 132.67 \text { (irrigated area). } \\
\text { Fixed cost- } \$ 24.39 \text { (for dry land) and } \\
\$ 52.39 \text { (for irrigated area) }\end{array}$ & $\begin{array}{c}\text { Total } \\
\text { Cost } \\
\text { of the design } \\
=16000-18000 /-\end{array}$ \\
\hline Efficiency & $75-80 \%$ & $70-75 \%$ & $\begin{array}{l}\text { Model efficiency } \\
\quad=97 \%-99 \% \\
\text { Water efficiency } \\
\quad=80 \%-90 \%\end{array}$ \\
\hline
\end{tabular}

This table compares the cost and efficiency of the model that cultivate crops by reusing water with the model where the water is not reusing.

From the above table we can deduct that combined model of water reuse, food production costing is much lower than single system and its efficiency is high enough. The benefits are shown in the reuse system according to the efficiency and cost in comparison with single systems.

\subsection{Objective}

The objective was to develop a system which can reuse rain water in crop cultivation purpose. The optimal dimension and specification of the system was estimated as the Nature based optimization method. In total three designs were developed from the results of the optimization. The performance analysis of the three systems was carried out through three different water scenarios. The design which performance more optimally then the other was selected for real life applications. 


\subsection{Brief Methodology: Flowchart:}

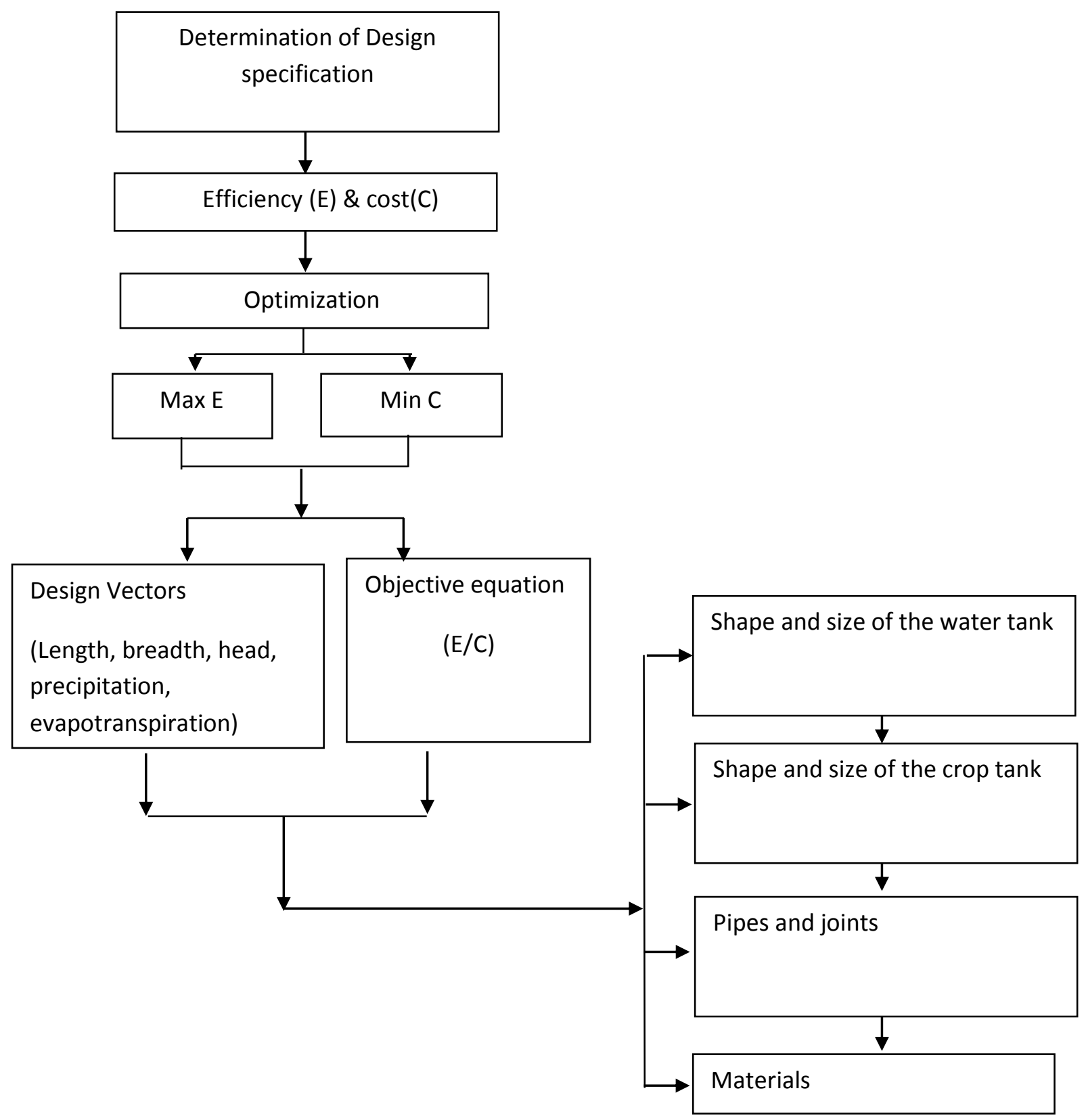

\subsubsection{Glowworm Swarm Optimization and Differential Evaluation}

Glowworm swarm optimization (GSO) and Differential Evaluation (DE) technology are use to find the optimal design specifications for yielding maximum crop efficiency under minimum expenditure.

\subsubsection{Identifications of Optimal Design Specification}

Three optimal design specifications have got by comparing the result of GSO optimization technique and DE technique.

\subsubsection{Performance Analysis of the Model}

The performance analyses of the three optimized design specifications are done by the help of the ANN-GMDH shell model. 


\subsubsection{Reliability and Uncertainty Testing}

The reliability and the uncertainty test are done on the design specifications of the model. This reliability is done with the help of Beers Law and uncertainty is done by Theil's Uncertainty coefficient (U).

\section{Literature Review:}

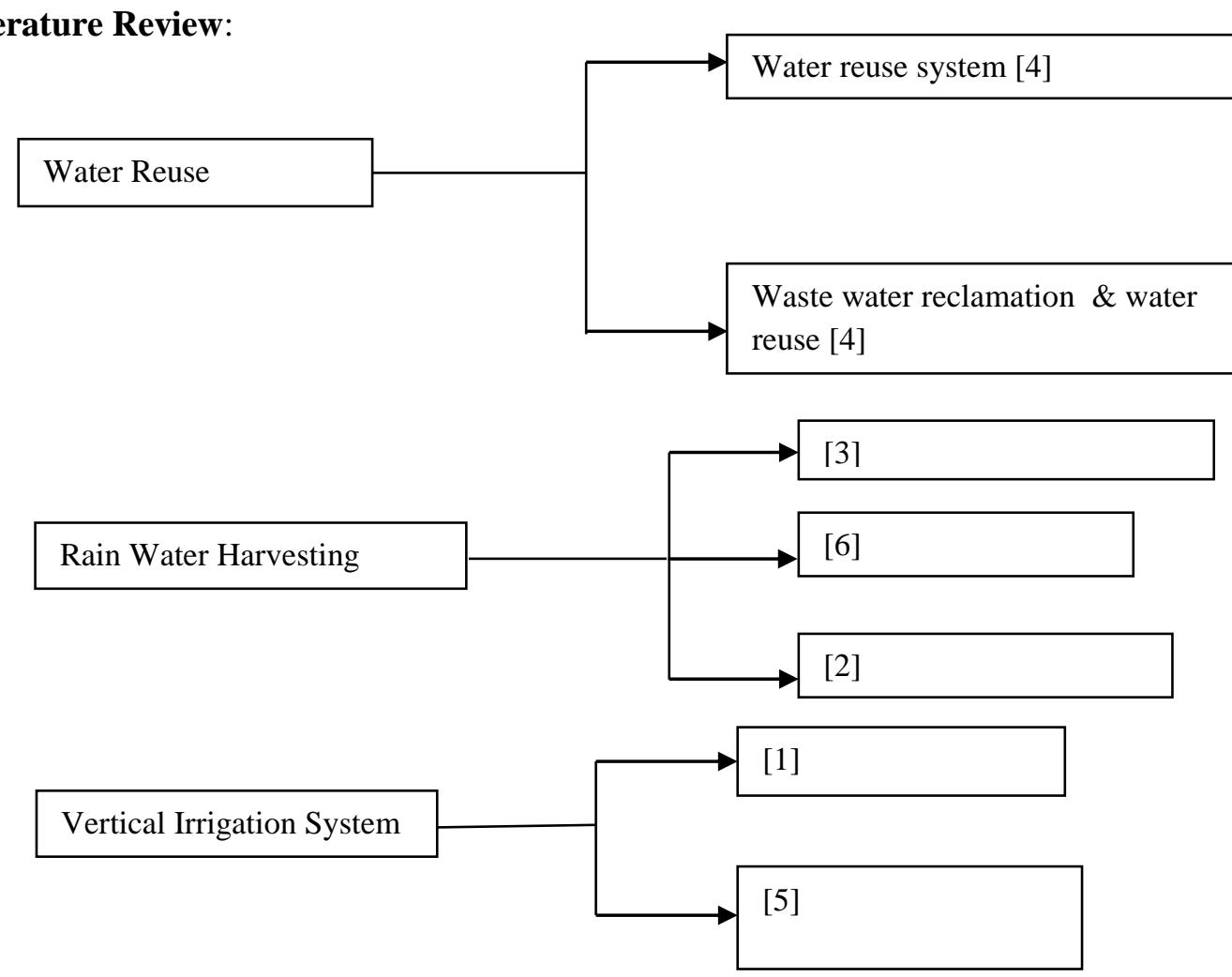

\section{Methodology}

\subsection{Methods Used}

The present study will require optimizing an objective function. The optimization was performed by two algorithms viz: DE \& GSO.

\subsubsection{Differential Evaluation Method}

It is a population based stochastic search global optimization technique. The three crucial parameter involved in DE is NP (number of population), $\mathrm{F}$ (scaling factor) and CR (Crossover rate) that significantly influence the optimization technique. Differential Evaluation technique used in power plant control [14], automatic generation control for interconnected power systems with non-linearity [15] and self-potential data generation [16] and neural network purpose [17].

The DE method can be applied in the real-valued problem over the continuous space [18]. It is similar to Genetic algorithm [19].

$$
\forall \mathrm{i} \in \mathrm{n}: D_{i}=X_{a}+F\left(X_{b}-X_{c}\right) \text {. Where } \mathrm{i}, \mathrm{a}, \mathrm{b}, \mathrm{c} \text { are distinct }
$$

$\mathrm{X}_{\mathrm{b}}$ and $\mathrm{X}_{\mathrm{c}}$ are randomly chosen and $\mathrm{X}_{\mathrm{a}}$ is chosen either randomly or the best population.

As this algorithm is a member of evolutionary group so it has all the merits of these algorithms: strong ability of global searching, versatility to problem features [20]. 


\subsubsection{Glowworm Swarm Optimization Method}

GSO is a nature inspired optimization technique that simulates the lighting worms' behavior. This algorithm is suitable for concurrent search of several solutions and also the equal objective function values.

In the GSO technique agents are randomly distributed in workspace. The agents in the glowworm algorithm carry a luminescence quantity known as luciferin. Agents are thought of as glowworm emits light whose intensity is proportional to the associated luciferin and also have a variable decision range $r_{i}^{d}$ which is bounded by circular sensor range $r_{s}$.

The GSO technique that $1^{\text {st }}$ initialize the parameters then update the luciferin value of the glowworm $\mathrm{i}$

$$
L_{i}(t)=(1-\rho) \times L_{i}(t-1)+\gamma J\left(X_{i}(t)\right)
$$

Glowworm search the similar condition using the equation

$$
N_{i}(t)=\left\{j:|| X j(t)-X i(t) \|<r_{d}^{i}, L i(t)<L j(t)\right.
$$

Then calculate the probability of distribution (Pij)

$$
P_{i j}=\frac{L j(t)-L i(t)}{\exists_{k \in N i(t)} L k(t)-L i(t)}
$$

$\&$ updating the movement by using the equation of $\mathrm{Xi}$

$$
X_{i}(t+1)=X i(t)+S \times\left[\frac{X j(t)-X i(t)}{\|X j(t)-X i(t)\|}\right.
$$

This GSO technique applied in several fields like multimodal functions where simultaneous capture of multiple local optima[21], clustering approach, scheduling of single machine etc.

This GSO has a multimodal search capability to locate optimal centroids. In addition with this it has flexible and robust in nature[22]. These are the reason for selecting the algorithm. There are some disadvantages like searching speed and accuracy are less [22].

\subsubsection{Development of the ANN Model and GMDH System}

Here the model is predicted by comparing these design variables with the help of ANN model design software named as GMDH shell. For designing this model we have to take the input of length, breadth, height, various kinds of losses and precipitation and evapotranspiration and the output of this model are efficiency-cost ratio.

\subsubsection{Theils Uncertainty Coefficient}

The U statistic developed by scientist Theils in the year of 1966 [25] for the measurement of the accuracy of the model that emphasizes the large error and also it gives the correlation between the forecast variable data. Scientist Makridakis [26] simplified the Theils formula which is shown below:

$$
U=\sqrt{\frac{\sum_{t=1}^{n-1}\left(\frac{F_{t+1}-Y_{t+1}}{Y_{t}}\right)^{\wedge} 2}{\sum_{t=1}^{n-1}\left(\frac{Y_{t+1}-Y_{t}}{Y_{t}}\right)^{\wedge} 2} \cdots}
$$

Where, $\mathrm{U}=$ Theils $\mathrm{U}$ coefficient, $\mathrm{F}=$ forecasting, $\mathrm{Y}=$ Observation

By the help of Beers law [27] we calculate the reliability of the model. It measures the $\%$ of reliability $\left(\mathrm{R}^{2}\right)$ which is also known as coefficient of determination. This coefficient of determination is calculated on the basis rainfall-power graph. This graph shows the value of $R^{2}$. The beers law formula is 


$$
\begin{aligned}
I & =I_{0} \times 10^{-(\alpha \times l \times c)} \ldots \ldots \\
\alpha & =\frac{A}{l \times c} \ldots . .
\end{aligned}
$$

Where, $\mathrm{I}=$ Intensity of the light passing through spectrometer, $\mathrm{I}_{0}=$ Amount of light intensity incident on sample, $\mathrm{l}=$ distance travel by light, $\mathrm{c}=$ concentration of absorber and $\alpha=$ absorption coefficient.

\subsection{Details Methodology}

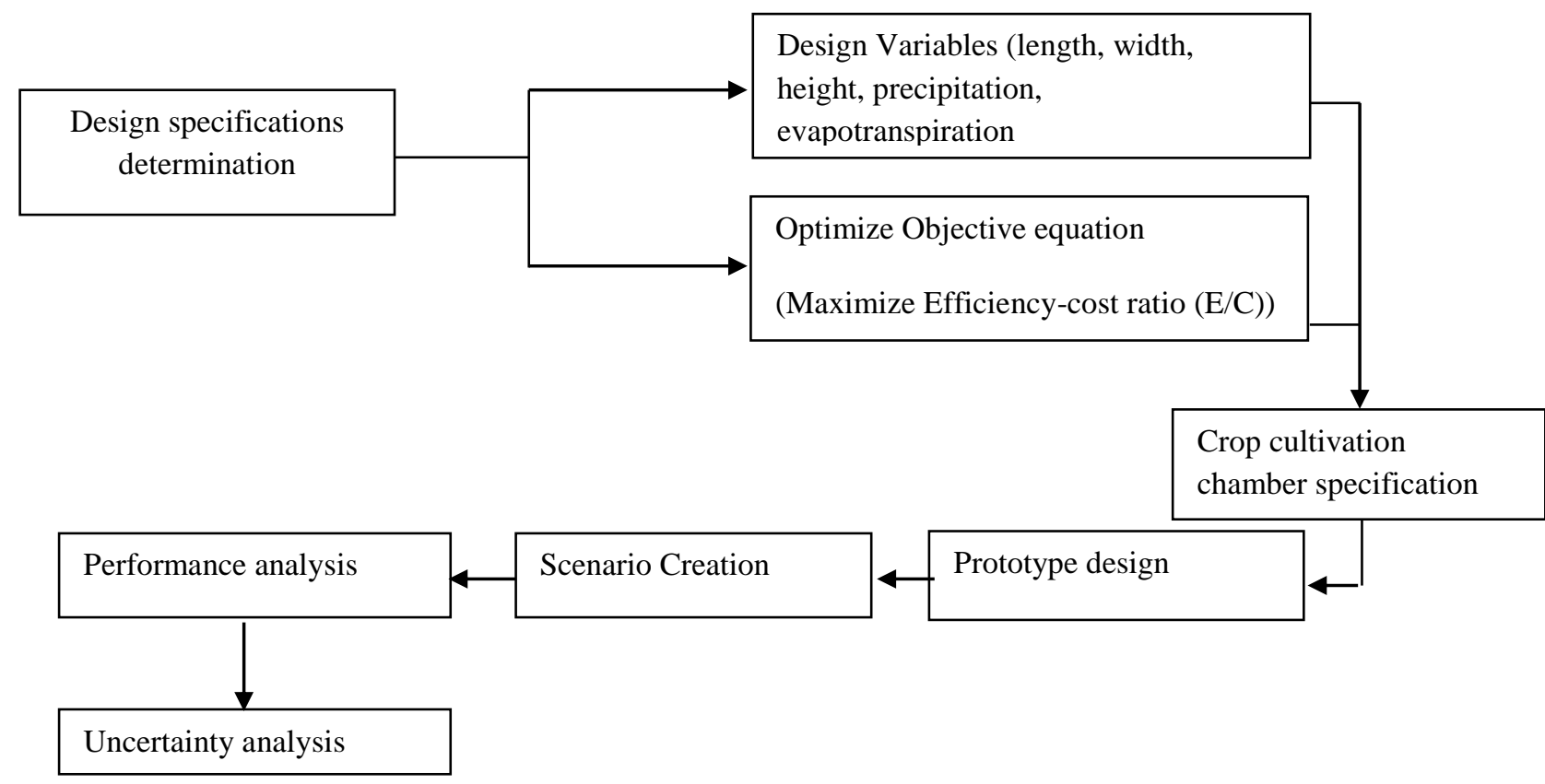

The comparison of main two optimization technique GSO and DE gives the optimal design specification. These three dataset are taken on the basis of maximum efficiencycost ratio.

\subsubsection{Design Variables}

The main considerable design variables for designing objective equation is length (1), width (b), head (h) of the tanks. The several losses like dynamo loss $\left(\Delta \mathrm{V}_{\mathrm{d}}\right)$, water quantity loss in soil for crop production $\left(\Delta \mathrm{V}_{\mathrm{s}}\right)$, evapotranspiration loss $\left(\Delta \mathrm{V}_{\mathrm{e}}\right)$, pump loss $\left(\Delta \mathrm{V}_{\text {pump }}\right)$ are consider as a variables for the objective equation. Under the climatic variables precipitation $(\mathrm{P})$ and evapotranspiration $(\mathrm{Et})$ are mostly needed design variables. With the help of Optimization tools we are able to find the maximum efficiency by minimizing the installation cost of this model.

\subsubsection{Necessary Assumptions and Constraints}

For this objective equation we take a few assumptions for maximizing the food efficiency of model and under minimum cost. The aim is to maximize the efficiency-cost ratio of the system. The boundary has to take in a feasible range for the length, width and height of the tank. We consider the losses as constraints which is range in between the 01. Literature reveals the last 10 years value of the rainfall and evapotranspiration from which we get the minimum and maximum value of this. 
Table 2. Constraints Applied to the Design Variables

\begin{tabular}{|c|c|c|c|c|c|c|c|}
\hline Variable & $\begin{array}{l}\text { Length(l) } \\
\text { (m) }\end{array}$ & $\begin{array}{c}\text { Width(b) } \\
\text { (m) }\end{array}$ & $\begin{array}{c}\text { Height(h) } \\
\text { (m) }\end{array}$ & $\begin{array}{c}\text { Total } \\
\text { Height } \\
\text { (m) }\end{array}$ & Losses & $\begin{array}{c}(\mathrm{P}) \\
\text { (m/month) }\end{array}$ & $\begin{array}{c}\text { (Et) } \\
\text { (m/month) }\end{array}$ \\
\hline Min & 0.61 & 0.61 & 0.61 & 0.61 & 0 & 0.007 & 0.004 \\
\hline Max & 1.22 & 1.22 & 1.22 & 4.57 & 1 & 0.22 & 0.04 \\
\hline
\end{tabular}

The above table shows the feasible range of the design variables. The optimization techniques are used this range for generate the design specifications where the efficiencycost ratio is maximum.

\subsubsection{Objective Equation}

The main objective equation is the model efficiency and cost ratio:

$\frac{\operatorname{Efficiency}(E)}{\operatorname{Cost}(C)}=\frac{\left.(l \times b \times h)-\Delta \mathrm{Vd}-\Delta \mathrm{Vs}-\Delta \mathrm{V}_{\text {eva }}-\Delta \mathrm{V}_{\text {pump }}\right) / V_{1}}{\{P+(v+V) \times r\}+\left\{(l+L) \times r_{p}\right\}+\left(S \times r_{s}+g \times r_{g}+s t \times r_{s t}\right)} \ldots \ldots \ldots$

Using this above equation maximum efficiency-cost ratio has to decide by the help of optimization procedure. The objective equations are developed depending on the variables. The procedures of that optimization are briefly discussed in step wise manner.

$\mathrm{V}_{1}=$ Reservoir volume (input Water volume)

$=1 * \mathrm{~b} * \mathrm{~h}$ where $\mathrm{l}, \mathrm{b}$ and $\mathrm{h}$ is reservoir length, breadth and height

$\mathrm{V}_{2}$ and $\mathrm{V}_{3}$ is volume of water in $2^{\text {nd }}$ and $3^{\text {rd }}$ tank. $\mathrm{V}_{4}$ is output water

\section{Efficiency Maximization Equation}

Power generation equation : $P=\rho \times g \times Q \times H \ldots \ldots \ldots$

Where, $\rho=$ water density, $\mathrm{Q}=$ discharge of water, $\mathrm{H}=$ height /depth of the tank 1

$Q=\{(p-E t) \times l \times b\}+\Delta V_{\text {pump }} \ldots \ldots$

Putting the equation 1 in equation 2: $P=\rho \times g \times H \times\{(p-E t) \times l \times b\}+\Delta V_{\text {pump }}$

Where, $\mathrm{p}=$ precipitation, $\mathrm{ET}=$ evapotranspiration, $1 \& \mathrm{~b}=$ length and breadth and $\Delta \mathrm{V}_{\text {pump }}$ $=$ Water through pump which are used to uplift the water from lower to upper reservoir

$V_{2}=\mathrm{V}_{1}-\Delta V_{D}$

Where $\Delta \mathrm{V}_{\mathrm{D}}=$ volume of water passes through dynamo: $V_{3}=V_{2}-\Delta \mathrm{Vs}$

Where $\Delta \mathrm{Vs}=$ volume of water stored in the $2^{\text {nd }}$ tank: $V_{3}=(l \times b \times h)-\Delta \mathrm{Vd}-$ $\Delta V s \ldots \ldots . .(15)$

$$
\begin{array}{r}
V_{4}=V_{3}-\Delta \mathrm{V}_{\text {eva }}-\Delta \mathrm{V}_{\text {pump }} \\
V_{4}=(l \times b \times h)-\Delta \mathrm{Vd}-\Delta \mathrm{Vs}-\Delta \mathrm{V}_{\text {eva }}-\Delta \mathrm{V}_{\text {pump }}
\end{array}
$$


Energy, $E=V_{4} / V_{1}$

Efficiency $=\left(V_{4}=(l \times b \times h)-\Delta \mathrm{Vd}-\Delta \mathrm{Vs}-\Delta \mathrm{V}_{\text {eva }}-\Delta \mathrm{V}_{\text {pump }}\right) / V_{1}$.

\section{Cost Minimization}

Initial costing:-

Labour cost: $\mathrm{P}$

Types of material: $r$

Total volume of material:- $(l * b * h)+(m * n * o)=v+V$

Where, $v=$ volume of water in the $1^{\text {st }}$ tank.

$\mathrm{V}=$ volume of another tank

$\mathrm{L}=$ length of $1^{\text {st }}$ penstock

$\mathrm{L}=$ length of $2^{\text {nd }}$ penstock

Cost $\odot:-C=\{(v+V) \times r\}+\left\{(l+L) \times r_{p}\right\}$

HRF costing: $S \times r_{s}+g \times r_{g}+s t \times r_{s t}$

Where, $S=$ sand $r_{s}=$ cost of sand

$\mathrm{g}=$ gravel and $\mathrm{r}_{\mathrm{g}}=$ cost of the gravel

$\mathrm{st}=$ stone and $\mathrm{r}_{\mathrm{st}}=$ cost of stone

Total cost: $C=\{P+(v+V) \times r\}+\left\{(l+L) \times r_{p}\right\}+\left(S \times r_{s}+g \times r_{g}+s t \times r_{s t}\right)$

\subsubsection{Penstock Diameter Calculation}

Discharge

$$
Q=A \times V
$$

Where, $A=$ area of the pipe $\& V=$ velocity of water through pipe

From Bernoulli's Equation,

$$
\frac{V^{2}}{2 \times g}+\frac{P}{\rho \times g}+Z=H
$$

Where, $\mathrm{V}=$ Velocity of water, $\mathrm{P}=$ pressure of water, $\rho=$ density of fluid at all point of fluid, $\mathrm{g}=$ acceleration due to gravity, $\mathrm{Z}=$ elevation of the point above a reference plane and $\mathrm{H}=$ total head.

Here,

$$
P=F \times A
$$

Where, $\mathrm{F}=$ force of the fluid and $\mathrm{A}=$ area of the tank

$$
\text { Again area of the pipe } \quad A=\pi \times r^{2} \ldots \ldots \text { (24) } \mathrm{r}=\text { radius of the pipe }
$$

\subsubsection{Programming Technique}

The nature based optimization algorithm: DE and GSO was used as a programming technique for the present optimization problem. 


\subsection{Design of the Prototype}

This model is a multipurpose water reuse and crop cultivation system. In this model there are mainly 3 parts are present. $1^{\text {st }}$ part is used for micro hydro power generation, $2^{\text {nd }}$ part is for crop productivity and $3^{\text {rd }}$ one is used for drinking water purpose. In that $1^{\text {st }}$ part rain water is captured in the reservoir. The stored water of reservoir passes through penstock and its rotate the dynamo blade and produce electricity. After the electricity generation procedure the water comes to the $2^{\text {nd }}$ reservoir and the water is stored in the $2^{\text {nd }}$ reservoir for crop cultivation. The chick pea, mustard seed all are suitable for the cultivation purpose in that chamber. If this prototype developed it can able sell the crop and the drinking water we can reimburse the installation cost.

The basic structure of this model is prepared. The 2D and 3D layout is given below.

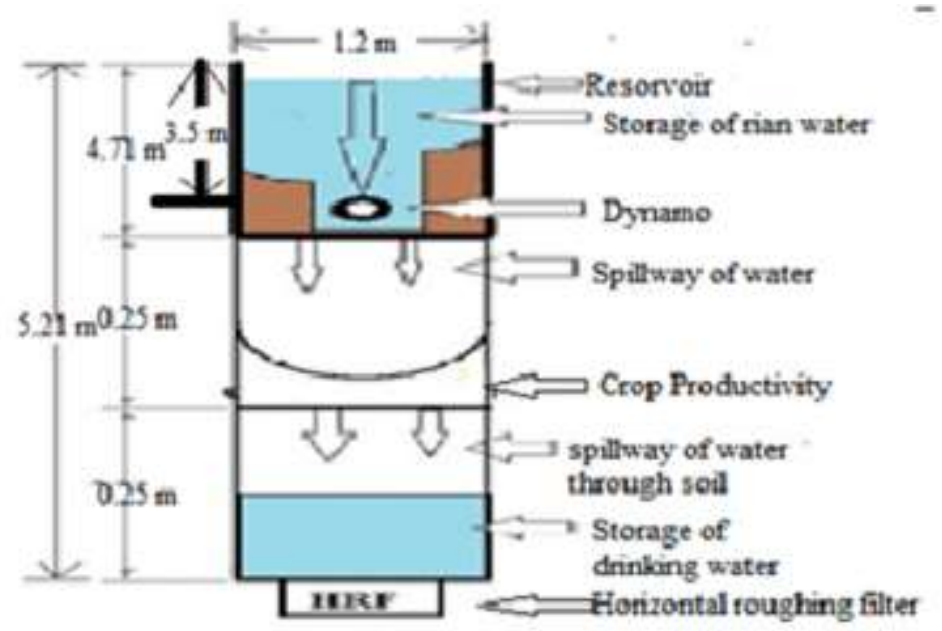

Figure 1. 2D Layout of Water Energy Efficiency Model

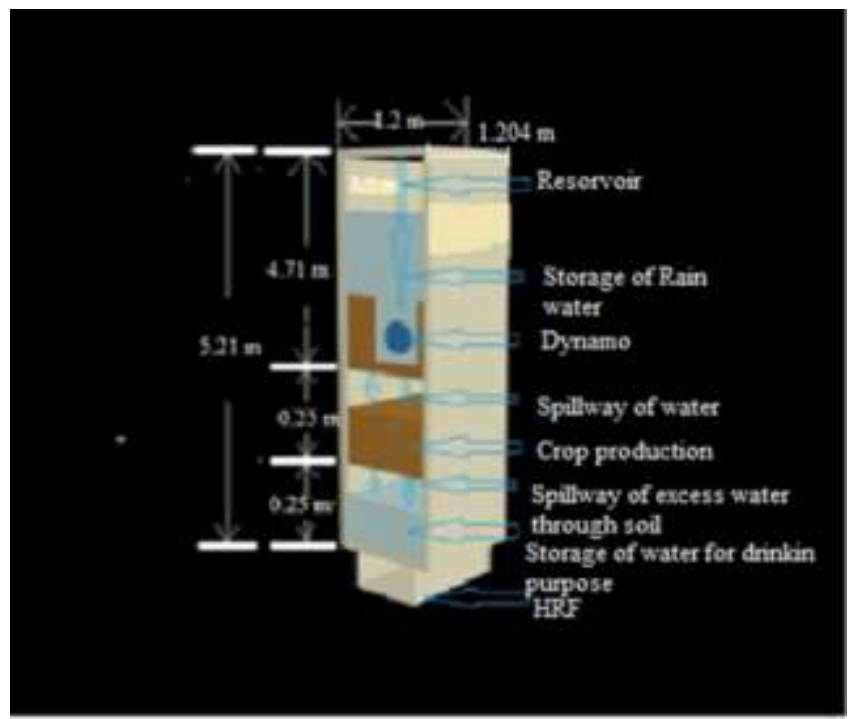

Figure 2. 3D Layout of Water Energy Efficiency Model

Above figures shows the schematic diagram of the model in 2D and 3D layout of the model. 


\subsubsection{Model Development for Performance Analysis of the Design System}

This three optimized design specifications are developed with the help of optimization technique. This design specification is tested with the help of ANN model.

This ANN model is done in the GMDH software. Here the input variables length, breadth and height. The output and the target values are efficiency-cost ratio. The datasets are import in that software and then it is forecast the data for prediction purpose. The equations are generated with the help of the sub-models. ANN model is prediction based models which is useful to develop accurate model and to generate the error of the model by comparing predicted and accurate data.

\subsubsection{Scenario Creation}

Design Scenario: Scenario analysis is the process of analyzing possible future events by considering alternative possible outcomes. It is the main method of the projection of a model. It can be used in an exploratory manner for the purpose of scientific assessment for understanding the functioning of an investigated system [28].

A. Food demands (Certain crop like mustard oil for a person):

In a single household mustard oil is a basic need. If we consider the basic household demand of mustard oil for a single persons use is $400 \mathrm{ml}$ per month. This scenario is created by increasing and decreasing the maximum and minimum precipitation in 10 intervals respectively.

Model various demand scenarios:

Table 3. Food Demand Scenario of the Most Optimal Design (Design 2)

\begin{tabular}{|c|c|c|c|c|c|c|c|c|c|c|c|}
\hline $\begin{array}{l}\text { Food } \\
\text { Demand } \\
\text { Per day }\end{array}$ & $\begin{array}{l}\text { Length } \\
\text { (m) }\end{array}$ & $\begin{array}{l}\text { Breadth } \\
\text { (m) }\end{array}$ & $\begin{array}{l}\text { Head } \\
\text { (m) }\end{array}$ & $\Delta \mathbf{V}_{\mathbf{d}}$ & $\Delta \mathbf{V}_{\mathrm{s}}$ & $\Delta \mathbf{V}_{\text {eva }}$ & $\Delta \mathbf{V}_{\text {pump }}$ & $\begin{array}{l}\text { Preci } \\
\text { (m/mon) }\end{array}$ & $\begin{array}{l}\text { Evapo } \\
\text { (m/mon) }\end{array}$ & $\begin{array}{l}\text { Oil } \\
\text { production } \\
\text { from crop }\end{array}$ & Eff/cost \\
\hline $430 \mathrm{ml}$ & 1.18 & 1.21 & 1.22 & 0.197 & 0.19 & 0.038 & 0.66 & 0.227 & 0.069 & $418 \mathrm{ml}$ & 0.0784 \\
\hline $420 \mathrm{ml}$ & 1.18 & 1.21 & 1.22 & 0.197 & 0.19 & 0.038 & 0.66 & 0.227 & 0.069 & $418 \mathrm{ml}$ & 0.0784 \\
\hline $410 \mathrm{ml}$ & 1.18 & 1.21 & 1.22 & 0.197 & 0.19 & 0.038 & 0.66 & 0.227 & 0.069 & $418 \mathrm{ml}$ & 0.0784 \\
\hline $400 \mathrm{ml}$ & 1.18 & 1.21 & 1.22 & 0.197 & 0.19 & 0.038 & 0.66 & 0.227 & 0.069 & $418 \mathrm{ml}$ & 0.0784 \\
\hline $390 \mathrm{ml}$ & 1.18 & 1.21 & 1.22 & 0.197 & 0.19 & 0.038 & 0.66 & 0.227 & 0.069 & $418 \mathrm{ml}$ & 0.0784 \\
\hline $380 \mathrm{ml}$ & 1.18 & 1.21 & 1.22 & 0.197 & 0.19 & 0.038 & 0.66 & 0.227 & 0.069 & $418 \mathrm{ml}$ & 0.0784 \\
\hline
\end{tabular}

Table 4. Food Demand Scenario of the $2^{\text {nd }}$ Optimal Design (Design 1)

\begin{tabular}{|l|l|l|l|l|l|l|l|l|l|l|l|}
\hline $\begin{array}{l}\text { Food } \\
\text { Demand } \\
\text { (per } \\
\text { day) }\end{array}$ & $\begin{array}{l}\text { Length } \\
(\mathbf{m})\end{array}$ & $\begin{array}{l}\text { Breadth } \\
(\mathbf{m})\end{array}$ & $\begin{array}{l}\text { Head } \\
(\mathbf{m})\end{array}$ & $\Delta \mathbf{V}_{\mathbf{d}}$ & $\Delta \mathbf{V}_{\mathbf{s}}$ & $\Delta \mathbf{V}_{\text {eva }}$ & $\Delta \mathbf{V}_{\text {pump }}$ & $\begin{array}{l}\text { Preci } \\
(\mathbf{m} / \mathbf{m o n})\end{array}$ & $\begin{array}{l}\text { Evapo } \\
(\mathbf{m} / \mathbf{m o n})\end{array}$ & $\begin{array}{l}\text { Crop } \\
\text { Production }\end{array}$ & \begin{tabular}{l} 
Eff/cost \\
\hline $430 \mathrm{ml}$
\end{tabular} \\
\hline 1.05 & 1.134 & 1.2 & 0.337 & 0.22 & 0.44 & 0.56 & 0.197 & 0.069 & $340 \mathrm{ml}$ & 0.0754 \\
\hline $420 \mathrm{ml}$ & 1.05 & 1.134 & 1.2 & 0.337 & 0.22 & 0.44 & 0.56 & 0.197 & 0.069 & $340 \mathrm{ml}$ & 0.0754 \\
\hline
\end{tabular}




\begin{tabular}{|l|l|l|l|l|l|l|l|l|l|l|l|l|}
\hline $410 \mathrm{ml}$ & 1.05 & 1.134 & 1.2 & 0.337 & 0.22 & 0.44 & 0.56 & 0.197 & 0.069 & $340 \mathrm{ml}$ & 0.0754 \\
\hline $400 \mathrm{ml}$ & 1.05 & 1.134 & 1.2 & 0.337 & 0.22 & 0.44 & 0.56 & 0.197 & 0.069 & $340 \mathrm{ml}$ & 0.0754 \\
\hline $390 \mathrm{ml}$ & 1.05 & 1.134 & 1.2 & 0.337 & 0.22 & 0.44 & 0.56 & 0.197 & 0.069 & $340 \mathrm{ml}$ & 0.0754 \\
\hline $380 \mathrm{ml}$ & 1.05 & 1.134 & 1.2 & 0.337 & 0.22 & 0.44 & 0.56 & 0.197 & 0.069 & $340 \mathrm{ml}$ & 0.0754 \\
\hline
\end{tabular}

Table 5. Food Demand Scenario of the $3^{\text {rd }}$ Optimal Design (Design 3)

\begin{tabular}{|c|c|c|c|c|c|c|c|c|c|c|c|}
\hline $\begin{array}{c}\text { Food Demand } \\
\text { Per day }\end{array}$ & $\begin{array}{l}\text { Length } \\
\text { (m) }\end{array}$ & $\begin{array}{l}\text { Breadth } \\
\text { (m) }\end{array}$ & $\begin{array}{l}\text { Head } \\
\text { (m) }\end{array}$ & $\Delta V d$ & $\Delta \mathbf{V s}$ & $\Delta$ Veva & $\Delta$ Vpump & $\begin{array}{l}\text { Preci } \\
\text { (m/mon) }\end{array}$ & $\begin{array}{l}\text { Evapo } \\
\text { (m/mon) }\end{array}$ & $\begin{array}{l}\text { Crop } \\
\text { Production }\end{array}$ & Eff/cost \\
\hline $430 \mathrm{ml}$ & 1.16 & 1.3 & 1.2 & 0.37 & 0.22 & 0.44 & 0.26 & 0.127 & 0.058 & $377 \mathrm{ml}$ & 0.0731 \\
\hline $420 \mathrm{ml}$ & 1.16 & 1.3 & 1.2 & 0.37 & 0.22 & .44 & 0.26 & 0.127 & 0.058 & $377 \mathrm{ml}$ & 0.0731 \\
\hline $410 \mathrm{ml}$ & 1.16 & 1.3 & 1.2 & 0.37 & 0.22 & .44 & 0.26 & 0.127 & 0.058 & $377 \mathrm{ml}$ & 0.0731 \\
\hline $400 \mathrm{ml}$ & 1.16 & 1.3 & 1.2 & 0.37 & 0.22 & .44 & 0.26 & 0.127 & 0.058 & $377 \mathrm{ml}$ & 0.0731 \\
\hline $390 \mathrm{ml}$ & 1.16 & 1.3 & 1.2 & 0.37 & 0.22 & .44 & 0.26 & 0.127 & 0.058 & $377 \mathrm{ml}$ & 0.0731 \\
\hline $380 \mathrm{ml}$ & 1.16 & 1.3 & 1.2 & 0.37 & 0.22 & .44 & 0.26 & 0.127 & 0.058 & $377 \mathrm{ml}$ & 0.0731 \\
\hline
\end{tabular}

\subsubsection{Model Reliability \& Uncertainty}

In the Uncertainty testing part Theils U coefficient calculation followed several steps:

1) Calculate the Probability $P(X)$ of variable $X$ and also the conditional Probability of distribution Variable $\mathrm{P}(\mathrm{X}$ ! Y).

2) The next we have to calculate the entropy of the single and conditional Probability

$$
\begin{aligned}
& H(X)=P_{x}^{(X)} \times \log P_{x}^{(X)} \\
& H(X ! Y)=P_{x, y}^{(X ! Y)} \times \log P_{x, y}^{(X ! Y)}
\end{aligned}
$$

3) The Uncertainty coefficient $U$ is calculated based on the above equation:

$U=\frac{H(X)-H(X ! Y)}{H(X)}$

This Theils coefficient Result shows that predicted model uncertainty.

\section{Result}

\subsection{Optimization Result}

By using the optimization techniques like DE and GSO three design specifications are determined. After few iteration process in both optimization technique comparisons are done and the three optimum design specifications are selected. 
Table 6. Design 1 Dimensions and Specifications

\begin{tabular}{|c|c|c|c|c|c|c|c|c|}
\hline & $\begin{array}{l}\text { Mini } \\
\text { Mum }\end{array}$ & $\begin{array}{l}\text { Maxi } \\
\text { Mum }\end{array}$ & $\begin{array}{l}\text { Value } \\
\text { (m) }\end{array}$ & Weightage & $\begin{array}{l}\text { Discharge } \\
\left(\mathrm{m}^{\wedge} 3 / \text { day }\right)\end{array}$ & $\begin{array}{l}\text { Crop } \\
\text { Production } \\
\text { (gm/mon) }\end{array}$ & $\begin{array}{l}\text { Amount of } \\
\text { water use and } \\
\text { reuse }\end{array}$ & Cost \\
\hline Length & 0.61 & 1.22 & 1.058025 & 1.021922 & \multirow{10}{*}{0.536897} & \multirow{10}{*}{$\begin{array}{l}708.6 \text { gm per } \\
\text { month }=340 \\
\text { ml }\end{array}$} & \multirow{10}{*}{$\begin{array}{l}\text { Water use }= \\
1443 \text { litre } \\
\text { Reuse } \\
\text { water }=11831 \\
=39 \text { litre per } \\
\text { day }\end{array}$} & \multirow{10}{*}{$\begin{array}{l}\text { Installation } \\
\text { Cost in Rs } \\
19899\end{array}$} \\
\hline breadth & 0.61 & 1.22 & 1.134135 & 1.368133 & & & & \\
\hline height & 0.61 & 1.22 & 1.202697 & 1.522644 & & & & \\
\hline $\begin{array}{l}\text { Gross } \\
\text { Height }\end{array}$ & 0.61 & 4.57 & 4.53 & 1.16 & & & & \\
\hline$\Delta \mathrm{Vd}$ & 0 & 1 & 0.337231 & 1 & & & & \\
\hline$\Delta \mathrm{Vs}$ & 0 & 1 & 0.219254 & 1.349579 & & & & \\
\hline$\Delta$ Veva & 0 & 1 & 0.438471 & 1.375635 & & & & \\
\hline$\Delta \mathrm{V}_{\text {pump }}$ & 0 & 1 & 0.562553 & 1.428328 & & & & \\
\hline Preci & 0.007 & 0.23 & 0.197633 & 0.762258 & & & & \\
\hline evapotra & 0.004 & 0.4 & 0.069014 & 1.036356 & & & & \\
\hline
\end{tabular}

Table 7. Design 2 Dimensions and Specifications

\begin{tabular}{|c|c|c|c|c|c|c|c|c|}
\hline & $\begin{array}{l}\text { Mini } \\
\text { Mum }\end{array}$ & $\begin{array}{l}\text { Maxi } \\
\text { Mum }\end{array}$ & $\begin{array}{l}\text { Value } \\
(\mathrm{m})\end{array}$ & Weightage & $\begin{array}{l}\text { Discharge } \\
\left(\mathrm{m}^{\wedge} 3 / \text { day }\right)\end{array}$ & $\begin{array}{l}\text { Crop } \\
\text { Production } \\
\text { (gm/mon) }\end{array}$ & $\begin{array}{l}\text { Amount of } \\
\text { water use and } \\
\text { reuse }\end{array}$ & Cost \\
\hline Length & 0.61 & 1.22 & 1.188025 & 1.121922 & \multirow{10}{*}{0.576897} & \multirow{10}{*}{$\begin{array}{l}872 \text { gm per } \\
\text { month }=418 \\
\text { ml }\end{array}$} & \multirow{10}{*}{$\begin{array}{l}\text { Water use = } \\
1768 \text { litre } \\
\text { Reused } \\
\text { water }=1514 \text { l= } \\
50 \text { litre per } \\
\text { day }\end{array}$} & \multirow{10}{*}{$\begin{array}{l}\text { Installation } \\
\text { Cost in Rs } \\
19560\end{array}$} \\
\hline breadth & 0.61 & 1.22 & 1.214135 & 1.368133 & & & & \\
\hline height & 0.61 & 1.22 & 1.22697 & 1.522644 & & & & \\
\hline $\begin{array}{l}\text { Gross } \\
\text { Height }\end{array}$ & 0.61 & 4.57 & 4.57 & 1.16 & & & & \\
\hline$\Delta \mathrm{Vd}$ & 0 & 1 & 0.197231 & 1.54 & & & & \\
\hline$\Delta \mathrm{Vs}$ & 0 & 1 & 0.19254 & 1.349579 & & & & \\
\hline$\Delta$ Veva & 0 & 1 & 0.038471 & 1.375635 & & & & \\
\hline$\Delta \mathrm{V}_{\text {pump }}$ & 0 & 1 & 0.662553 & 1.428328 & & & & \\
\hline Preci & 0.007 & 0.23 & 0.227633 & 0.762258 & & & & \\
\hline evapotra & 0.004 & 0.4 & 0.069014 & 1.036356 & & & & \\
\hline
\end{tabular}

Table 8. Design 3 Dimensions and Specifications

\begin{tabular}{|c|c|c|c|c|c|c|c|c|}
\hline & $\begin{array}{l}\text { Mini } \\
\text { Mum }\end{array}$ & $\begin{array}{l}\text { Maxi } \\
\text { Mum }\end{array}$ & $\begin{array}{l}\text { Value } \\
\text { (m) }\end{array}$ & Weightage & $\begin{array}{l}\text { Discharge } \\
\left(\mathrm{m}^{\wedge} 3 / \text { day }\right)\end{array}$ & $\begin{array}{l}\text { Crop } \\
\text { Production } \\
\text { (gm/mon) }\end{array}$ & $\begin{array}{l}\text { Amount of } \\
\text { water use and } \\
\text { reuse }\end{array}$ & Cost \\
\hline Length & 0.61 & 1.22 & 1.168025 & 1.21922 & \multirow{10}{*}{0.456897} & \multirow{10}{*}{$\begin{array}{l}786 \mathrm{gm} \text { per } \\
\text { month }=377 \\
\text { ml }\end{array}$} & \multirow{10}{*}{$\begin{array}{l}\text { Water use = } \\
1572 \text { litre } \\
\text { Reuse } \\
\text { water }=1282 \text { l= } \\
38 \text { litre per } \\
\text { day }\end{array}$} & \multirow{10}{*}{$\begin{array}{l}\text { Installation } \\
\text { Cost in Rs } \\
19989\end{array}$} \\
\hline breadth & 0.61 & 1.22 & 1.134135 & 1.268133 & & & & \\
\hline height & 0.61 & 1.22 & 1.202697 & 1.22644 & & & & \\
\hline $\begin{array}{l}\text { Gross } \\
\text { Height }\end{array}$ & 0.61 & 4.57 & 4.5 & 1.1 & & & & \\
\hline$\Delta \mathrm{Vd}$ & 0 & 1 & 0.37231 & 1.87 & & & & \\
\hline$\Delta \mathrm{Vs}$ & 0 & 1 & 0.219254 & 1.49579 & & & & \\
\hline$\Delta$ Veva & 0 & 1 & 0.438471 & 1.275635 & & & & \\
\hline$\Delta \mathrm{V}_{\text {pump }}$ & 0 & 1 & 0.262553 & 1.228328 & & & & \\
\hline Preci & 0.007 & 0.23 & 0.127633 & 1.762258 & & & & \\
\hline evapotra & 0.004 & 0.4 & 0.058014 & 1.036356 & & & & \\
\hline
\end{tabular}




\subsubsection{The Optimization Result (3D graphical view):}

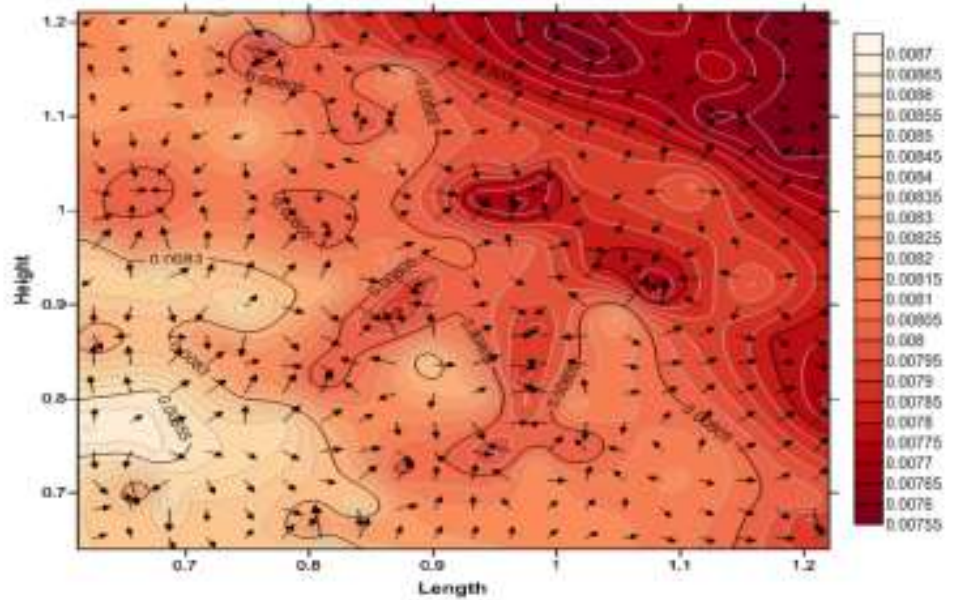

Figure 3. The Efficiency-Cost Ratio Variation with Respect to Length and Height of the Reservoir

In the $3 \mathrm{D}$ graph if the data's are set in the $1^{\text {st }}$ quadrant then the graph is said to be accurate. In this graph the model optimal design values are laying in the $1^{\text {st }}$ quadrant of the graph and that satisfies the models accuracy.

In the Table 9 the normalized values of cost and efficiency are taken with respect to the volume of reservoir. These values are taken on the basis of optimization result. Then taking these normalized values of cost and efficiency two graphs are drawn with respect to the volume. These two graphs cut at the same point. This meeting point is the optimum point and this design is optimum design.

Table 9. Normalized Value of the Design

\begin{tabular}{|c|c|c|c|}
\hline Design & Volume & Cost & Efficiency \\
\hline Design 1 & 0.30 & 0.33 & 0.33 \\
\hline Design 3 & 0.33 & 0.34 & 0.33 \\
\hline Design 2 & 0.37 & 0.33 & 0.34 \\
\hline
\end{tabular}

\section{Optimal Cost/Efficiency Curve}

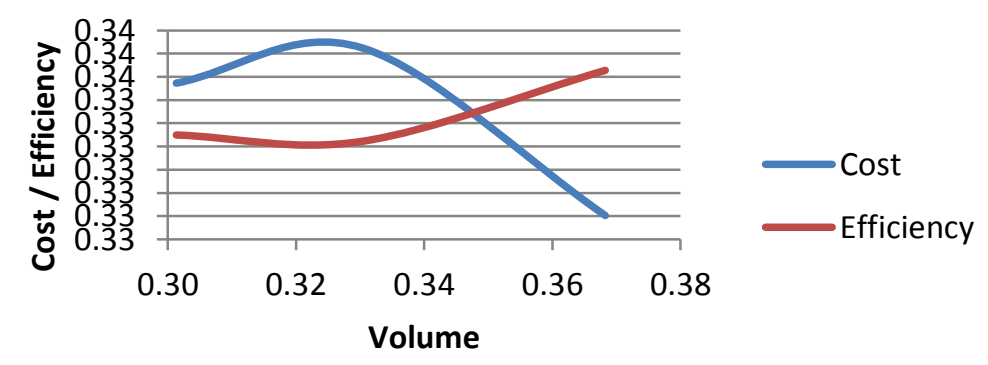

Figure 4. Graphical Representation of Optimum Design 


\subsubsection{Penstock Diameter Calculation}

$\mathrm{Q}=0.019 \mathrm{~m}^{3} / \mathrm{day}, \mathrm{g}=9.81, \rho=999.9 \mathrm{~kg} / \mathrm{m}^{3}, \mathrm{~F}=$ force of water in the tank $=1359$ litre water force $=.3331 \mathrm{~N}, \mathrm{~A}=1.49 \mathrm{~m}^{2}$.

By putting this value in the equation 16 we get, $V=6.23 \mathrm{~m} /$ day.

$$
\begin{gathered}
Q=A \times V \\
0.019=A \times 6.23 \\
\mathrm{~A}=0.00305 \mathrm{~m}^{2} \\
A=\pi \times r^{2} \\
\mathrm{r}=0.09 \mathrm{~m}=3.54 \mathrm{inch} \\
\text { Diameter }=7 \text { inch }
\end{gathered}
$$

\begin{tabular}{|c|c|c|c|c|c|c|c|c|c|c|c|c|}
\hline $\begin{array}{l}\text { Food } \\
\text { Demand } \\
\text { Per day }\end{array}$ & $\begin{array}{l}\text { Length } \\
\text { (m) }\end{array}$ & $\begin{array}{l}\text { Breadth } \\
\text { (m) }\end{array}$ & $\begin{array}{l}\text { Head } \\
(\mathrm{m})\end{array}$ & $\Delta \mathrm{V}_{\mathrm{d}}$ & $\Delta \mathrm{V}_{\mathrm{s}}$ & $\Delta \mathrm{V}_{\text {eva }}$ & $\Delta \mathrm{V}_{\text {pump }}$ & $\begin{array}{l}\text { Preci } \\
(\mathrm{m} / \mathrm{mon})\end{array}$ & $\begin{array}{l}\text { Evapo } \\
\text { (m/mon) }\end{array}$ & $\begin{array}{l}\text { Crop } \\
\text { Production }\end{array}$ & Eff/cost & com \\
\hline $430 \mathrm{ml}$ & 1.05 & 1.134 & 1.2 & 0.337 & 0.22 & 0.44 & 0.56 & 0.197 & 0.069 & $340 \mathrm{ml}$ & 0.0754 & $90 \mathrm{ml} \mathrm{def}$ \\
\hline $420 \mathrm{ml}$ & 1.05 & 1.134 & 1.2 & 0.337 & 0.22 & 0.44 & 0.56 & 0.197 & 0.069 & $340 \mathrm{ml}$ & 0.0754 & $80 \mathrm{ml} \mathrm{def}$ \\
\hline $410 \mathrm{ml}$ & 1.05 & 1.134 & 1.2 & 0.337 & 0.22 & 0.44 & 0.56 & 0.197 & 0.069 & $340 \mathrm{ml}$ & 0.0754 & $70 \mathrm{ml} \mathrm{def}$ \\
\hline $400 \mathrm{ml}$ & 1.05 & 1.134 & 1.2 & 0.337 & 0.22 & 0.44 & 0.56 & 0.197 & 0.069 & $340 \mathrm{ml}$ & 0.0754 & $60 \mathrm{ml}$ def \\
\hline $390 \mathrm{ml}$ & 1.05 & 1.134 & 1.2 & 0.337 & 0.22 & 0.44 & 0.56 & 0.197 & 0.069 & $340 \mathrm{ml}$ & 0.0754 & $50 \mathrm{ml} \mathrm{def}$ \\
\hline $380 \mathrm{ml}$ & 1.05 & 1.134 & 1.2 & 0.337 & 0.22 & 0.44 & 0.56 & 0.197 & 0.069 & $340 \mathrm{ml}$ & 0.0754 & $40 \mathrm{ml} \mathrm{def}$ \\
\hline
\end{tabular}

So the pipe diameter $=7$ inch.

\subsubsection{Demand Scenario Result of the Model}

Table 10. Food Demand Scenario of the most Optimal Design (Design 2)

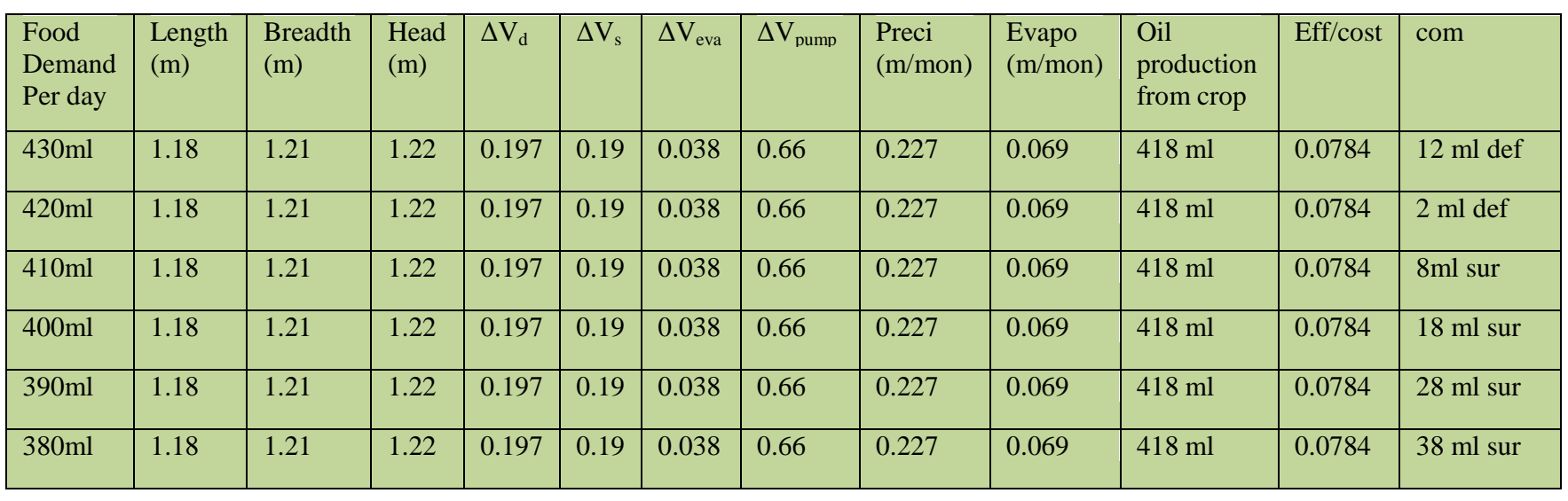

Table 11. Food Demand Scenario of the $2^{\text {nd }}$ Optimal Design (Design 1)

Table 12: Food demand scenario of the $3^{\text {rd }}$ optimal design (Design 3) 


\begin{tabular}{|l|l|l|l|l|l|l|l|l|l|l|l|l|}
\hline $\begin{array}{l}\text { Food } \\
\text { Demand } \\
\text { Per day }\end{array}$ & $\begin{array}{l}\text { Length } \\
(\mathrm{m})\end{array}$ & $\begin{array}{l}\text { Breadth } \\
(\mathrm{m})\end{array}$ & $\begin{array}{l}\text { Head } \\
(\mathrm{m})\end{array}$ & $\Delta \mathrm{V}_{\mathrm{d}}$ & $\Delta \mathrm{V}_{\mathrm{s}}$ & $\Delta \mathrm{V}_{\text {eva }}$ & $\Delta \mathrm{V}_{\text {pump }}$ & $\begin{array}{l}\text { Preci } \\
(\mathrm{m} / \mathrm{mon})\end{array}$ & $\begin{array}{l}\text { Evapo } \\
(\mathrm{m} / \mathrm{mon})\end{array}$ & $\begin{array}{l}\text { Crop } \\
\text { Production }\end{array}$ & Eff/cost & com \\
\hline $430 \mathrm{ml}$ & 1.16 & 1.3 & 1.2 & 0.37 & 0.22 & 0.44 & 0.26 & 0.127 & 0.058 & $377 \mathrm{ml}$ & 0.0731 & $\begin{array}{l}53 \\
\text { Def }\end{array}$ \\
\hline $420 \mathrm{ml}$ & 1.16 & 1.3 & 1.2 & 0.37 & 0.22 & .44 & 0.26 & 0.127 & 0.058 & $377 \mathrm{ml}$ & 0.0731 & $\begin{array}{l}43 \\
\text { def }\end{array}$ \\
\hline $410 \mathrm{ml}$ & 1.16 & 1.3 & 1.2 & 0.37 & 0.22 & .44 & 0.26 & 0.127 & 0.058 & $377 \mathrm{ml}$ & 0.0731 & $\begin{array}{l}33 \\
\text { def }\end{array}$ \\
\hline $400 \mathrm{ml}$ & 1.16 & 1.3 & 1.2 & 0.37 & 0.22 & .44 & 0.26 & 0.127 & 0.058 & $377 \mathrm{ml}$ & 0.0731 & $\begin{array}{l}23 \\
\text { def }\end{array}$ \\
\hline $390 \mathrm{ml}$ & 1.16 & 1.3 & 1.2 & 0.37 & 0.22 & .44 & 0.26 & 0.127 & 0.058 & $377 \mathrm{ml}$ & 0.0731 & $\begin{array}{l}13 \\
\text { def }\end{array}$ \\
\hline $380 \mathrm{ml}$ & 1.16 & 1.3 & 1.2 & 0.37 & 0.22 & .44 & 0.26 & 0.127 & 0.058 & $377 \mathrm{ml}$ & 0.0731 & $\begin{array}{l}3 \\
\text { def }\end{array}$ \\
\hline
\end{tabular}

\subsubsection{Performance Analysis of the Model}

The model is tested through ANN and it's developing the predicted model for the output of the prototype. By generating the ANN predicted model we can able to develop the prototype equation based on which this can be develop in future.

The several prototype design variables are:

\section{Efficiency-cost ratio}

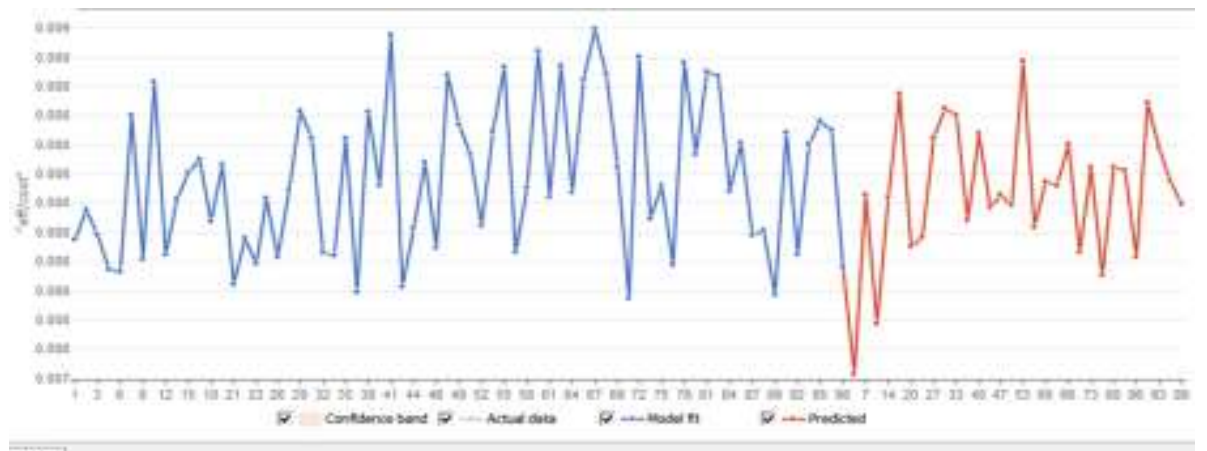

Figure 5. Efficiency/cost Actual vs Predicted Plot

This plot shows the actual result versus predicted result curve which is drawn based on actual and predicted result. After testing the result prediction model are developed. 


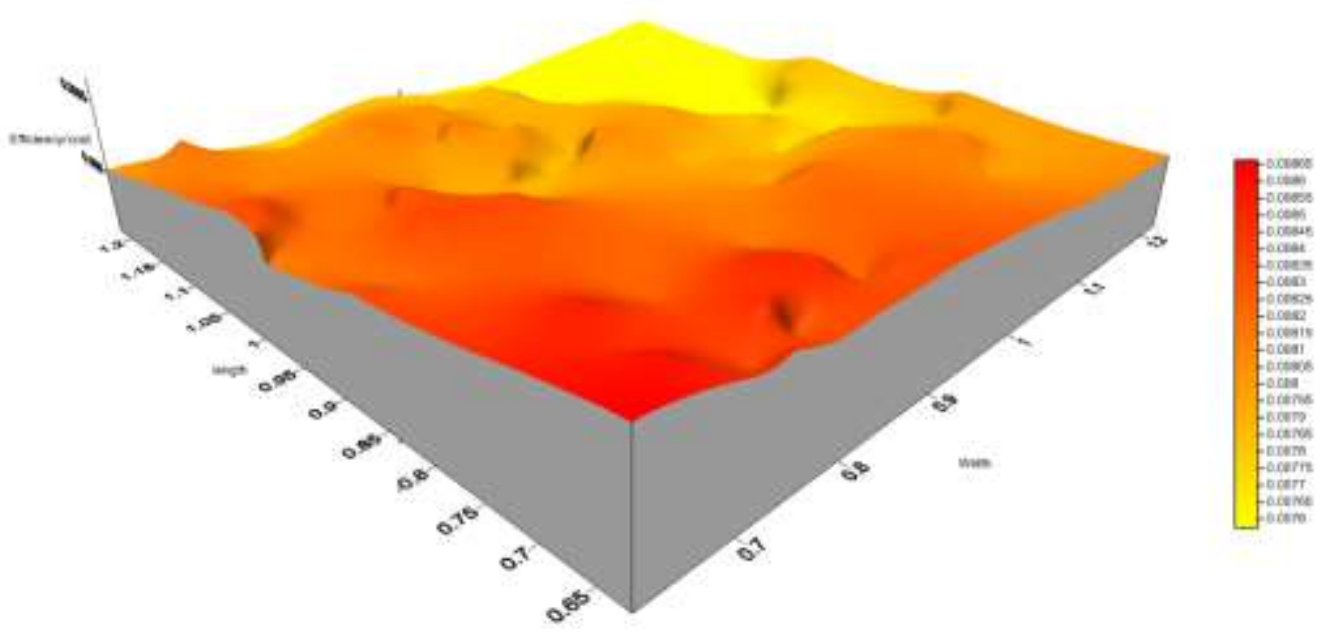

Figure 6. Efficiency-cost Ratio Variation with Length and Width

This surface curve determines the variations of efficiency-cost ratio with respect to length and width.

Table 13. Accuracy Result

\begin{tabular}{|l|l|l|}
\hline Post processed Result & \multicolumn{1}{|c|}{ Model fit } & \multicolumn{1}{c|}{ Prediction } \\
\hline Number of observation & 69 & 30 \\
\hline Normalized mean absolute error & $0.107 \%$ & $0.208 \%$ \\
\hline Normalized root mean square error & $0.236 \%$ & 0.235 \\
\hline Standard deviation of residuals & $0.236 \%$ & $0.234 \%$ \\
\hline Coefficient of determination $\left(\mathrm{R}^{2}\right)$ & 0.999 & 0.9991 \\
\hline Correlation & 0.9996 & 0.9995 \\
\hline
\end{tabular}

The accuracy table shows the model accuracy results. The correlation of the predicted model is 0.9995 and the coefficient of determination is 0.9991 . From this it is easily said that the above model is accurate enough. The erroneous value is also minimum for the model.

The basic equation which is used to calculate the predicted model result is:

$Y 1=0.000274828-N 538 * 0.0377175+N 538 * N 2 * 4.09231+N 2 *$ 0.970611

\subsubsection{Reliability and Uncertainty Testing of the Model}

Theil's Uncertainty Coefficient $(\mathrm{U})=\frac{1.403814-1.396006}{1.403814}=0.005562$. This uncertainty shows that model uncertainty is 0.005562 . 
Reliability Analysis:

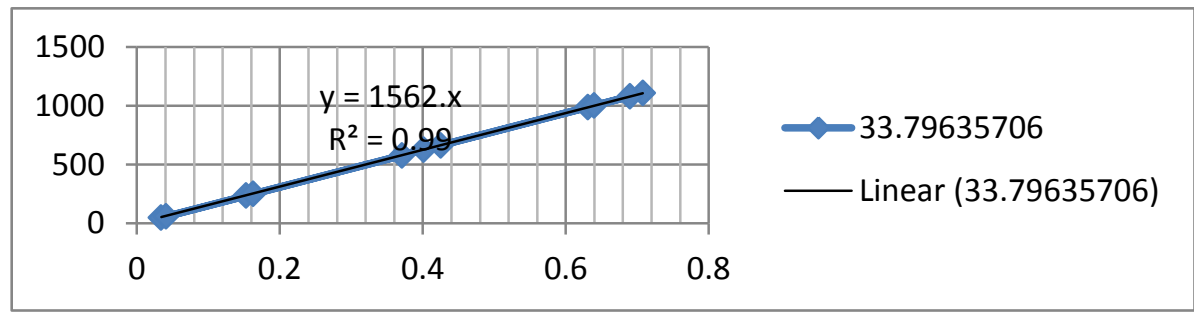

Figure 7. Reliability Curve of the Model

Coefficient of Determination $\left(\mathrm{R}^{2}\right)=0.99$

The model is $99 \%$ reliable which is shown from the coefficient of determination value.

\section{Discussions}

In this model development purpose we optimize the design specifications based on several parameters which are the basic variables for maximum food production and water reuse of this model. We use the optimization process and developed three design specifications. The DE and GSO are the two program technique gives the suitable result among the several optimization programs. Among these three specifications after comparing the various design scenarios for all the specifications optimal design is generated. The best design specifications are generated through comparing scenario criteria which is given below.

Table 14. Food Demand Scenario vs Design Table

\begin{tabular}{|l|l|l|}
\hline \multicolumn{1}{|c|}{ Scenario } & Food demand scenario & Food Demand Scenario \\
\hline Design & Low & $\begin{array}{l}\text { Here food demand does not } \\
\text { satisfied and deficiency } \\
\text { varies from 40ml-90ml }\end{array}$ \\
\hline Design 2 & Medium & $\begin{array}{l}\text { Here above 420ml oil } \\
\text { deficiency occurs but } \\
\text { under this surplus of oil } \\
\text { varies from 8ml-38ml }\end{array}$ \\
\hline Design 3 & Low & $\begin{array}{l}\text { Here food demand does not } \\
\text { satisfied and deficiency } \\
\text { varies from 3ml-53ml }\end{array}$ \\
\hline
\end{tabular}

According to the Table it is clearly seen that Design 2 is best suitable result for satisfying this overall demand scenario among the other design. This design satisfies the basic demand criteria and also gives the higher efficiency-cost ratio rather than other two designs. This model solves a major problem of the society.

The prototype model provides a new tool to conserve both water and food. The system can also create a source of income from the crop produced generated from the system.

JIANG and LI [6], reviewed the advantages of rainwater using in the agricultural field and in the domestic purpose. This rainwater harvesting, the collection and storage of rainfall runoff is widely used in arid and semiarid regions of China. The water use efficiency ranged from $0.7-5.7 \mathrm{~kg} / \mathrm{m}^{3}$ for spring wheat, corn and flax and $30-40 \mathrm{~kg} / \mathrm{m}^{3}$ for vegetables. Rain water increase the crop yields upto $30 \%$ in the supplemental irrigation system. Moreover, energy consumption for rain water supply to household purpose is 
very much less than traditional water supply. The advantageous side of rain water harvesting in the agricultural and domestic purpose is low cost, high energy efficiency, less adaptation and simple operation.

Helmreich and Horn [3], analyze the opportunity in rain water harvesting system. In proper management precipitation can reduce the water and food crisis of the regions. Rainwater constitutes a potential source of drinking water as well as agriculture purpose also. This harvested rainwater can be effectively used for rain fed agriculture and drinking water purpose in a single household. This rainwater might be polluted by bacteria and microbes sometimes so it should be filtered through roughing filters and then water can be used for drinking purpose.

Naddeo, Scannapieco [29], describes an innovative and decentralized system which can be used to collect and treat rainwater for potable use like drinking and cooking purposes. These systems can fulfill a single household demand or a small community.

Thus the new system can help any individual to ensure food security. Thereby a scientific implication of this model is that this model can serve the crop cultivation purpose. The design can able to solve the food problem of the rural area.

\section{Conclusion}

The current scenario the water and food are reducing day by day as per demand. Due to the high increase rate of demand-consumption ratio the future generation is going to face the food scarcity after some years later. Taking this into the consideration we try to develop the model which will produce a food through rain water with the same water. This is a mini model which can setup at low cost which will produce $418 \mathrm{ml}$ oil which is sufficient for the single household purposes. The main advantage of this model is we use and reuse the water for several times which reduce the installation cost upto 50\% comparing with separate model and efficiency is also high.

As a future work we can reduce the maintenance cost of this model, increasing the number of iteration in the process for getting much suitable result and minimize the losses, maximize the soil efficiency to increase crop productivity and also the costing of this material have to minimize. The time taken by the pump for uplift water will have to calculate in the future work. From this calculation we can minimize the time lag of the system by adding some other features or able to improve the piping system of the prototype. By utilizing this model, the future demands of electricity and water can be minimized to some extent.

\section{References}

[1] D. Despommier, "The vertical farm: feeding the world in the 21st century", Macmillan, (2010).

[2] A. Pacey and A. Cullis, "Rainwater harvesting: the collection of rainfall and runoff in rural areas", Intermediate technology publications, (1986).

[3] B. Helmreich and H. Horn, "Opportunities in rainwater harvesting", Desalination, vol. 248, no. 1, (2009), pp. 118-124.

[4] D. Chang and Z. Ma, "Wastewater reclamation and reuse in Beijing: Influence factors and policy implications", Desalination, vol. 297, (2012), pp. 72-78.

[5] I. Carruthers, M. W. Rosegrant and D. Seckler, "Irrigation and food security in the 21 st century", Irrigation and Drainage Systems, vol. 11, no. 2, (1997), pp. 83-101.

[6] Z.-y. Jiang and X.-y. Li, "Water and energy conservation of rainwater harvesting system in the Loess Plateau of China", Journal of Integrative Agriculture, vol. 12, no. 8, (2013), pp. 1389-1395.

[7] F. Ewert, "Future scenarios of European agricultural land use: I. Estimating changes in crop productivity”, Agriculture, Ecosystems \& Environment, vol. 107, no. 2, (2005), pp. 101-116.

[8] A. K. Gain and C. Giupponi, "A dynamic assessment of water scarcity risk in the Lower Brahmaputra River Basin: An integrated approach”, Ecological Indicators, vol. 48, (2015), pp. 120-131.

[9] T. W. Hertel, "The global supply and demand for agricultural land in 2050: A perfect storm in the making?", American Journal of Agricultural Economics, vol. 93, no. 2, (2011), pp. 259-275.

[10] H. Geman and P. V. Eleuterio, "Investing in fertilizer-mining companies in times of food scarcity", Resources Policy, vol. 38, no. 4, (2013), pp. 470-480. 
[11] C. Banerjee and L. Adenaeuer, Up, up and away! The economics of vertical farming. Journal of Agricultural Studies, 2014. 2(1): p. 40-60.

[12] Verma, S.C., J.K. Ladha, and A.K. Tripathi, Evaluation of plant growth promoting and colonization ability of endophytic diazotrophs from deep water rice. Journal of Biotechnology, 2001. 91(2): p. 127141.

[13] Pavlista, A., et al., Planting date and development of spring-seeded irrigated canola, brown mustard and camelina. Industrial crops and products, 2011. 33(2): p. 451-456.

[14] Cai, H., C. Chung, and K. Wong, Application of differential evolution algorithm for transient stability constrained optimal power flow. Power Systems, IEEE Transactions on, 2008. 23(2): p. 719-728.

[15] Mohanty, B., S. Panda, and P. Hota, Controller parameters tuning of differential evolution algorithm and its application to load frequency control of multi-source power system. International Journal of Electrical Power \& Energy Systems, 2014. 54: p. 77-85.

[16] Wang, J., et al., An annual load forecasting model based on support vector regression with differential evolution algorithm. Applied Energy, 2012. 94: p. 65-70.

[17] Ilonen, J., J.-K. Kamarainen, and J. Lampinen, Differential evolution training algorithm for feed-forward neural networks. Neural Processing Letters, 2003. 17(1): p. 93-105.

[18] Mallipeddi, R. and P.N. Suganthan, Differential evolution algorithm with ensemble of parameters and mutation and crossover strategies, in Swarm, Evolutionary, and Memetic Computing. 2010, Springer. p. 71-78.

[19] KARABOĞA, D. and S. Ökdem, A simple and global optimization algorithm for engineering problems: differential evolution algorithm. Turkish Journal of Electrical Engineering \& Computer Sciences, 2004. 12(1): p. 53-60.

[20] Qing, A. and C.K. Lee, Differential evolution in electromagnetics. 2010: Springer.

[21] Krishnanand, K. and D. Ghose, Glowworm swarm optimization for simultaneous capture of multiple local optima of multimodal functions. Swarm intelligence, 2009. 3(2): p. 87-124.

[22] Aljarah, I. and S.A. Ludwig. A new clustering approach based on glowworm swarm optimization. in Evolutionary Computation (CEC), 2013 IEEE Congress on. 2013. IEEE

[23] Bourquin, J., et al., Pitfalls of artificial neural networks (ANN) modelling technique for data sets containing outlier measurements using a study on mixture properties of a direct compressed dosage form. European journal of pharmaceutical sciences, 1998. 7(1): p. 17-28.

[24] Stader, J. and A. Macintosh, Capability modelling and knowledge management, in Applications and Innovations in Intelligent Systems VII. 2000, Springer. p. 33-50.

[25] Nellis, W., et al., Shock compression of liquid carbon monoxide and methane to $90 \mathrm{GPa}$ (900 kbar). The Journal of Chemical Physics, 1981. 75(6): p. 3055-3063.

[26] Makridakis, S., S.C. Wheelwright, and R.J. Hyndman, Forecasting methods and applications. 2008: John Wiley \& Sons.

[27] Murphy, J. and J.P. Riley, A modified single solution method for the determination of phosphate in natural waters. Analytica chimica acta, 1962. 27: p. 31-36.

[28] Foley, J.A., et al., Global consequences of land use. science, 2005. 309(5734): p. 570-574.

[29] Naddeo, V., D. Scannapieco, and V. Belgiorno, Enhanced drinking water supply through harvested rainwater treatment. Journal of Hydrology, 2013. 498: p. 287-291. 
International Journal of Advanced Science and Technology Vol.98 (2017) 